Meta

Journal des traducteurs

Translators' Journal

\title{
Human Pride Versus Parrotry Prejudice: Translating Clichés about Nigeria and the Blackman
}

\section{Debe Osaji}

Volume 31, numéro 4, décembre 1986

URI : https://id.erudit.org/iderudit/003767ar

DOI : https://doi.org/10.7202/003767ar

Aller au sommaire du numéro

Éditeur(s)

Les Presses de l'Université de Montréal

ISSN

0026-0452 (imprimé)

1492-1421 (numérique)

Découvrir la revue

Citer cette note

Osaji, D. (1986). Human Pride Versus Parrotry Prejudice: Translating Clichés about Nigeria and the Blackman. Meta, 31(4), 461-463.

https://doi.org/10.7202/003767ar d'utilisation que vous pouvez consulter en ligne. 


\section{HUMAN PRIDE VERSUS PARROTRY PREJUDICE: TRANSLATING CLICHÉS ABOUT NIGERIA AND THE BLACKMAN}

What is the best or the most important language in the world? The answer is simple and complex at the same time. From the speaker's point of view, it is the mother tongue. In the modern world however, from the national and international perspectives, what characterizes the beauty, the acceptability and the spread of a language is POWER. This power can be political, demographic, economic, religious, and, above all, military.

Such a "powerful" language, with its accompanying culture, - its morals, technology, skills, attitudes, values, laws and customs - has the contagious effect of stigmatizing, absorbing, assimilating or obliterating the "weak" languages or cultures. The colonisation of Africa and the third world countries by the European maritime powers in the past 500 years is a typical example of culture spread resulting in language imposition.

The English language today in Nigeria is the legacy of such a contact. It is full of words, expressions, nuances and subtle innuendos introduced by the English to express their racial prejudices against the black race. These elements have became clichés that continue to dominate English-language texts in Nigeria. The question that we, translators, need to answer is whether we should translate literally and thus parrot statements which we know deride our race and dehumanise us?

The inspiration for this article emanates from two sources. My major source of information is Ekundayo Simpson's elucidating work Samuel Beckett: traducteur de lui-même. Aspects de bilinguisme littéraire (Samuel Beckett: Self-translator, Aspects of literary bilingualism), published by The International Centre for Research on Bilingualism in 1978. The other source is an article by Chud Uwazurike in the Daily Times of May 14, 1981, under the caption "National Culture and Human Dignity."

Let us consider briefly certain fundamentals relevant to the theme of the paper. From Ekundayo Simpson's analysis ${ }^{1}$, one can distinguish three forms of translation: intralingual translation or reformulation which consists in the interpretation of a message using the linguistic signs of the same language; interlingual translation which is the interpretation of a message by means of linguistic signs from another language; and intersemiotic translation or transmutation which consists of interpretation making use of systems of non-linguistic signs, as in traffic lights or "no smoking" signs in public places. Of these three forms, the second, interlingual translation, is what is normally called translation. It is this form we are concerned with in this paper.

Another point fundamental to our study is the notion of absolute translability. Even though lan- guage can be considered as a "social art"2, communication among men implies "a certain dose of loss of information" ${ }^{\prime 3}$. This loss is natural in that we are intelligent human beings and not parrots. Whilst translating, the translator must take into account human realities, time and space elements, and this is bound to influence the final message, as Nida clearly points out.

If one is to insist that translation must involve no loss of information whatsoever, then obviously, not only translation but all communication is impossible. No communication, whether intralingual, interlingual, or intersemiotic, can occur without some loss of information. Even among experts discussing a subject within their own fields of specialization, it is unlikely that comprehension rises above the 80 per cent level. Loss of information is a part of the communication process, and hence the fact that some loss occurs in translation should not be surprising, nor should it constitute a basis for questioning the legitimacy of translating ${ }^{4}$

Here Nida, himself a renowned scholar and linguist, rejects the notion of absolute translability.

But this does not seem to be the case in Nigeria, where translators, academics, and above all the media - press, radio, television - appear to delight in the propagation and perpetuation of parrotry or unreflective translation, in the mistaken belief that this is the part to absolute translatability. In their "Word for Word" translation approach, they contribute further toward stigmatizing, degrading and dehumanizing their race and culture in the name of academic pedantry or servitude.

Take, for example, the word "tribe". This term, still used today in reference to Africa and the Third World, is highly pejorative. A reputable dictionary of current English defines it as "Group of primitive clans under an recognized chief"5. Tribe represents therefore the antithesis of civilisation, of modernity.

Anthropologically speaking, tribe refers to the rudimentary primitivety in social organisation more relevant to stone age men and the wandering baboon and chimpanzee race than to the well-organised societies of the nations of Asia and Africa ${ }^{6}$

And yet, for the white men and his media, the colourful turnout by Zaireans in 1980 to welcome the Bishop of Rome (Pope John Paul II) was a "tribal" festivity; the quarrels in Uganda are considered "tribal", rather than ideological, which suggests, for instance, that Obote and Muwanga, who supports Obote, are kith and kin; the politics of Nigeria are depicted as totally "tribal", not ethnocentric. But the agitation for autonomy in Wales and Scotland is described as "Welsh or Scottish nationalism"; the feud in Northern Ireland is considered a "civil strife due to religion differences"; the I.R.A. militancy is 
attributed to extreme irish nationalism, while the same phenomenon in Namibia is tagged as "S.W.A.P.O. gorilla of Ovamboland tribesmen trying to destroy Western Civilisation".

The core of my contention is not with the white man who uses his language to extol his culture and dignity, but with Nigerian translators, interpreters and media-men who thoughtlessly use both the foreign and local languages to insult their fatherland. Instead of looking for suitable equivalents and adaptations to reflect national culture and human dignity, these parrot interpreters and translators continue to perpetuate the whiteman's clichés. The mass media and the government are the worst offenders in this case. Their various articles and official documents (The Federal Housing Authority forms, the Federal and state government scholarships forms, etc.) bear the tags "tribe", "tribal", "indigene", "native", "dialect", "clan", etc., which are the clichés of primitivity or inferiority used by the almighty Oyibo.

Another striking example of such clichés is the term "black". Over the centuries this word Black has represented one of the stigmatized whiteconceived stereotypes, symbolising by and large anything that was and is evil. The devil and his cohorts are all painted pitch black (like blackmen), both in religious art and creative art, here in Nigeria as well as elsewhere. Black has come to stand for what is sinister, wicked and hated.

Allied terms and concepts, both conscious and unconscious, have arisen to further tarnish black and doom it to perpetual notoriety. The list of stereotype expressions containing the world "black" is long: black look meaning dirty look; black tidings meaning sad news; black deeds meaning wickedness; black mood implying bad temper; black art meaning witchcraft; black magic contrasting with white magic; black leg, euphemism for a saboteur; black list, having to do with unreliable or dangerous people; blackmail, black mark, black market, black head, black sheep, black-hearted, black-out, - al these and many other similar "black" expressions are found in popular usage.

But why black, when there is no viable parameter beyond subjective imagery that should equate black with evil? To be sure, the term "black" does occasionally have a positive connotation: black shoes, black suits, are popular in Europe; blackbox is very important in aircraft safety monitoring; and foreign statesmen love black limousines. But, these occasional positive usages of the word "black" do not compensate for the deep negative connotations it conveys.

Some people may not see the connection, but it depends on how far they truncate human action in favour of one thing and not the other: why inter-racial issues have always exhibited a Dr. Jekyll — and - Mr. Hyde syndrome (now excellent, now hideous) ${ }^{7}$

It is his time we rejected the humiliating clichés of the "black" and "tribal" variety and looked for ways of restoring national pride and dignity. This can be done. In fact, it has been done in the case of some of the following derogatory ethnic tags in the country, as a result or reactions against local clichés:

$\begin{array}{ll}\text { Gambari: } & \text { Yoruba for Hausa; } \\ \text { Kobo-kobo: } & \text { Yoruba for Igbo; } \\ \text { Ndi Mgbatoli: } & \text { Igbo for Yoruba; } \\ \text { Nyamiri: } & \text { Hausa for Igbo; } \\ \text { Ndi Gworo: } & \text { Igbo for Hausa; }\end{array}$

Munchi: Hausa for Tiv, etc.

These terms are normally resented by the groups affected. The translation or interpretation of a message containing them requires reflective use of equivalents and adaptations. By their persistent bitterness against the term Munchi, the Tivs have succeeded in obliterating the word from maps, printed material and even common parlance.

One wonders then why Nigerian scholars, media-men and translators have not reacted in a similar manner foreign stereotypes derogatory to their ethnic esteem? Why do they prefer servitude to remedial option in translation? Why can't they make use of translation theory and practice to show that culture is dynamic and not static?

It is a fact that language is given to us ready made. From that point of view, it constitutes servitudes to which we are constrained to submit: for example, the type of words, clichés, conjugation of verbs, agreement of words, etc. Within the limits imposed by these linguistic conventions, it is nevertheless possible to choose from existing resources, and it is this restricted liberty which constitutes what we call speech $^{8}$.

Where then does the real option in the use of a language come in? Obviously, when human dignity or racial pride is at stake, the conflicting choice or option arises. The translator must distinguish between what is imposed on the writer and what the latter uses freely. The distinction between servitude and option still remains valid. In the source language, that is, the language used in rendering the translation, it is the option which must retain our attention, whereas in the target language, that is the language of the translation, the translator must reckon both with the servitudes which impede his liberty of expression and with the options offered to him so that he can convey the nuances of the message.

The United States of America provides us with a striking word example of reflective translation. The term "negro" is pejorative in that country; is synonymous with sub-human social status, inferiority, primitivity, poverty, lack of intelligence, slavery, meanness. Intellectually, we know that like "caucasian", "negro" is a gencric term. But with racial bias, the whites loved daubbing the blacks with "negro" and at the same time avoided any allusion to the word "caucasian". How did the blacks react in that country? With violence en masse, of course. There was both physical and intellectual reaction. Black mass media, academia, and institutions rejected the cliché "negro" and adopted the term, "Black" or 
"Afro-American". This has forced the American society as a whole to recognize and accept officially the new reality as a fait accompli.

There is no reason why the new African reality cannot also become a fait accompli, with the active help of the media, scholars and translators. The press in our country, admittedly the most viable in Black Africa, should take the lead in combating the influence of derogatory terms in our national literature. Unfortunately, our newspapers and our academic institutions have not creatively fostered something that is both proudly African and of universal import. "While a national newspaper is for instance busy exhibiting traces of Americanisms, and while our academicians find such Latin expressions as sine qua non and non sequitur so erudite, such French expressions as joie de vivre and comme ci comme ça so fashionable, and such Japanese terms as samurai and kamikaze rather edifying"9. They seem unable to utter a word or a phrase of our real Nigerian language in the course of their speech.

If we really wish to rectify the huge stack of prejudices built up against our race over the centuries, the long-neglected film industry remains our greatest hope: it would do for us abroad what the press and academia could do for us at home if they had the right spirit. Films could serve as a means of propaganda, as an effective indirect way of disseminating information and truth, and as a construction approach to rectifying wrong notions and prejudices. We are the living witnesses to what the Indians, the Chinese and the Japanese have done for themselves in this field:

It in fact came as no surprise to me that the Golden Palm Award at the 1980 Cannes Film Festival was in part snatched by "The Double" - a Japanese historical saga produced by a Japanese, Akird Kurosawa, featuring Japanese actors. It is not only when you explode a nuclear device, admittedly, a great event, that you win global respect or private satisfaction 10

Finally, translators and interpreters could do their part in eliminating racial prejudices by adopting a more dynamic approach to translation. Perhaps a reference to Nida ${ }^{11}$ in Simpson's work ${ }^{12}$ will throw more light on the point I am trying to make. Nida identifies two types of equivalents in translation: the formal equivalent and the dynamic equivalent. Whereas the former sticks as closely as possible to the content and form of the source language, the latter tries to relate the source language to the time and space or the circumstances of the people of the target language. The dynamic equivalent is defined as "the closest natural equivalent to the sourcelanguage message". The key word is "natural", and Nida defines if as follows in the context of translation:

Basically, the word natural is applicable to three areas of the communication process; for a natural rendering must fit (1) the receptor language and culture as a whole, (2) the context of the particular message, and (3) the receptor - language audience ${ }^{13}$

From the above analysis, it is clear that in dynamic equivalence the emphasis is placed on the sense and realism of the message in terms of the receptor - language audience, rather than on the form and the wording. It is the type of translation that takes into account the culture, the people and their human psychology.

In the interests of national pride, racial awareness and human dignity in translation, our translators should adopt the dynamic and avoid the formal approach. The dynamic approach makes translation a reflective and human discipline. It enables the translator to replace the author's variations in a given text with equivalents that reflect a different language, time, place and tradition.

Translation should demonstrate that culture is not static, that it is pervasive and dynamic, and cannot therefore be controlled like a physical object. People and institutions involved in translation must develop a new attitude based on awareness of the psychological implications of certain notions, concepts and nuances: they must endeavour to restore to us our dignity by effecting linguistic transformations that make us masters of our own destiny. By so doing, they will not only play a crucial role in eliminating prejudices, but will also transform translation from parrotry to a reflective professional act.

\section{Debe OSAJI}

University of Lagos, Lagos, Nigeria

\section{Notes and References}

1. SIMPSON, E. (1978): Samuel Beckett: traducteur de lui-même. Aspects de bilinguisme littéraire, Québec, C.I.R.B., B79, ch. III, p. 37.

2. QUINE, W. Van O.: World and Object, quoted by E. Simpson, op. cit., p. 39. (The translation is mine.)

3. SIMPSON, E.: op. cit., p. 39. (The translation is mine.)

4. NIDA, E.: "A Framework for the Analysis and Evaluation of Theories of Translation", in Richard W. Brislain (ed.): Translation: Applications and Research, pp. 47-48. Quoted by E. Simpson, op. cit., ch. III, p. 40.

5. The Concise Oxford Dictionary of Current English, Fifth Edition, 1964 , p. 1388

6. UWAZURIKE, C. (1981): Daily Times, Lagos, May 14, p. 3

7. Ibid.

8. VINAY, J.-P. et J. DARBELNET (1958): Stylistique comparée du français et de langlais, Montréal, Beauchemin, p. 31. (The translation and adaptation are mine.)

9. UWAZURIKE, C.: op. cit.

9. UWA 1 loid.

11. NIDA, E.: op. cit

12. SIMPSON, E.: op. cit., pp. 46-47.

13. NIDA, E.: Toward a Science of Translating, pp. 166-167. Quoted by E. Simpson, op. cit., p. 47 